\title{
Isotopic Interpretation of Particulate Nitrate in the Metropolitan City of Karachi, Pakistan: Insight into the Oceanic Contribution to $\mathrm{NO}_{x}$
}

\author{
Zheng Zong, Chongguo Tian,* Jun Li,* Jabir Hussain Syed, Wei Zhang, Yunting Fang, Yifan Jiang, \\ Jawad Nasir, Muhammad Mansha, Syed Hussain Haider Rizvi, Muhammad Shafiq, Suhaib Bin Farhan, \\ and Gan Zhang
}

Cite This: Environ. Sci. Technol. 2020, 54, 7787-7797

Read Online

\section{ACCESS 1}

Џlll Metrics \& More

Article Recommendations

Supporting Information

ABSTRACT: Nitrogen oxide $\left(\mathrm{NO}_{x}\right)$ abatement has become the focus of air quality management strategies. In this study, we examined $\mathrm{NO}_{x}$ sources and the atmospheric conversion of $\mathrm{NO}_{x}$ in Karachi, Pakistan, a megacity in South Asia with serious particulate pollution problems. Oceanic contributions to $\mathrm{NO}_{x}$ were quantified for the first time based on a novel approach using nitrogen/oxygen isotopic analysis in nitrate $\left(\delta^{15} \mathrm{~N}-\mathrm{NO}_{3}^{-} ; \delta^{18} \mathrm{O}-\mathrm{NO}_{3}^{-}\right)$and a Bayesian model. Our results showed that $\delta^{15} \mathrm{~N}-\mathrm{NO}_{3}{ }^{-}$in Karachi varied between $-10.2 \%$ and $+12.4 \%$. As indicated by the $\delta^{18} \mathrm{O}-\mathrm{NO}_{3}{ }^{-}$findings $(+66.2 \pm 7.8 \%$ ), the $\bullet \mathrm{OH}$ pathway dominated $\mathrm{NO}_{x}$ conversion throughout the nearly two-year observation, but high $\mathrm{NO}_{3}{ }^{-}$events were attributed to the $\mathrm{O}_{3}$ pathway. Coal combustion was the most significant source (32.0 \pm

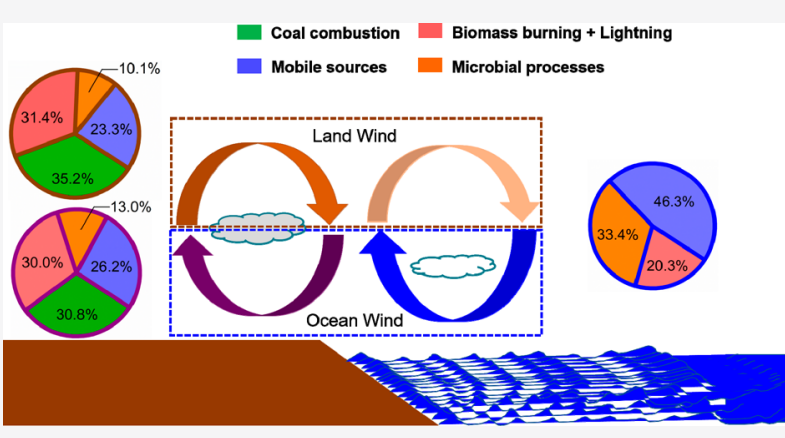
$9.8 \%)$ of $\mathrm{NO}_{x}$ in Karachi, with higher contributions in the autumn and winter; a similar situation occurred for biomass burning + lightning $(30.3 \pm 6.5 \%)$. However, mobile sources $(25.2 \pm 6.4 \%)$ and microbial processes $(12.5 \pm 7.5 \%)$ exhibited opposite seasonal trends. The oceanic contributions to $\mathrm{NO}_{x}$ in Karachi were estimated to be $16.8 \%$, of which lightning, shipping emissions, and microbial processes accounted for $20.3 \%, 46.3 \%$, and $33.4 \%$, respectively, emphasizing the dominance of shipping emissions as an oceanic $\mathrm{NO}_{x}$ source.

\section{INTRODUCTION}

Nitrogen oxides $\left(\mathrm{NO}_{x}\right.$, consisting mainly of $\mathrm{NO}$ and $\left.\mathrm{NO}_{2}\right)$ make up a large proportion of the reactive nitrogen and are the main precursors of particulate nitrate $\left(\mathrm{NO}_{3}{ }^{-}\right)$in the atmosphere. ${ }^{1} \mathrm{NO}_{x}$ is thought to be closely linked to a wide range of environmental issues, including ozone problems, acid rain, soil acidification, and increasingly serious particulate pollution (Supporting Information SI, Text S1). ${ }^{2-4}$ Thus, $\mathrm{NO}_{x}$ abatement has become the focus of pollution control and quantitative analysis of its emission a premise of governance. Generally, $\mathrm{NO}_{x}$ is emitted from a wide range of sources, including biomass burning, fossil energy consumption (e.g., coal combustion, vehicle exhaust, and shipping emissions), microbial processes, and lightning. ${ }^{5}$ These sources include emissions occurring over the terrain and ocean, respectively; however, presently, few source-parsed researches have been conducted and were typically focused on the former. ${ }^{6}$ In fact, oceanic sources, such as shipping emissions, lightning in ocean areas, and microbial processes in marine sediment and estuaries, are important contributors to $\mathrm{NO}_{x}$ emissions, especially in areas affected by ocean winds. ${ }^{6,7}$ Globally, about $15 \%$ of the world's $\mathrm{NO}_{x}$ is emitted from oceangoing ships, and
$5 \%-15 \%$ can be attributed to lightning. ${ }^{8}$ A simulation by Ding et al. indicated that shipping emissions contribute up to $5 \%-$ $20 \%$ to local $\mathrm{NO}_{x}$ concentrations in densely populated coastal regions of China. ${ }^{9}$ Therefore, the insufficient analysis of $\mathrm{NO}_{x}$ sources, especially quantifying the contributions of oceanic ones, complicates the mitigation efforts of $\mathrm{NO}_{x}$ pollution.

Several methods for apportioning $\mathrm{NO}_{x}$ emissions have been accepted, such as air quality models and satellite observations. ${ }^{9,10}$ However, each is accompanied by certain imperfections. As for air quality models, parameter setting could lead to source contributions that can differ in magnitude. A comparative study shows that for a particular data set the CAMx model results are usually $10 \%-20 \%$ higher than that of CMAQ. ${ }^{10}$ In satellite observations, it is still difficult to relate $\mathrm{NO}_{x}$ emissions to the derivative patterns (e.g., atmospheric

Received: January 23, 2020

Revised: $\quad$ May 8, 2020

Accepted: June 3, 2020

Published: June 3, 2020 
$\mathrm{NO}_{3}{ }^{-}$concentration and deposition) due to their extended lifetimes relative to $\mathrm{NO}_{x}$, which restricts its application. Compared with these simulations, the real-measured methods may better resolve the uncertainty in source apportionment of $\mathrm{NO}_{x}$. The nitrogen isotope technique using atmosphericderived nitrate $\left(\delta^{15} \mathrm{~N}-\mathrm{NO}_{3}{ }^{-}\right)$has been applied extensively to track $\mathrm{NO}_{3}{ }^{-}$and $\mathrm{NO}_{x}$ because the nitrogen isotopic signature of different $\mathrm{NO}_{x}$ sources generally varies over a large range. ${ }^{11-14}$ The technology roughly originated in the $1950 \mathrm{~s}$ and was mainly applied to the source analysis of $\mathrm{NO}_{3}{ }^{-}$in rainwater. ${ }^{15-17}$ For example, based on the feature of $\delta^{15} \mathrm{~N}-$ $\mathrm{NO}_{3}{ }^{-}$, Hoering postulated that $\mathrm{NO}_{3}{ }^{-}$in rain partly arose from the oxidation of ammonia. ${ }^{18}$ With the need of environmental governance, sources of $\mathrm{NO}_{3}^{-}$in aerosols are gradually apportioned by this technology, and $\mathrm{NO}_{3}{ }^{-}$targets also vary from TSP to $\mathrm{PM}_{10}$ to $\mathrm{PM}_{2.5} \cdot{ }^{14,19-23}$ For more detailed historical researches, please refer to SI Text S2 and Elliott et al. $^{24}$ In addition, $\delta^{15} \mathrm{~N}-\mathrm{NO}_{3}{ }^{-}$analysis results have steadily moved from qualitative to quantitative assessment. This progress is attributable to (i) continuous enrichment of the actual $\delta^{15} \mathrm{~N}-\mathrm{NO}_{x}$ source values detected, ${ }^{25-30}$ (ii) quantification of isotope fractionation that occurs with the conversion of $\mathrm{NO}_{x}$ to $\mathrm{NO}_{3}{ }^{-31,32}$ and (iii) the application of isotopic mixing models. ${ }^{33}$ In this context, the ability to quantify comprehensive $\delta^{15} \mathrm{~N}-\mathrm{NO}_{3}^{-}$analysis results (including the terrestrial and oceanic nature) is expected to facilitate mitigation and management efforts to reduce $\mathrm{NO}_{x}$ pollution levels.

South Asia is experiencing serious air quality issues (particulate pollution), resulting in a significant rise in health-related morbidity with chronic exposure to air pollution. ${ }^{34}$ Thereinto, Karachi, a metropolitan city in Pakistan with a population of 14.9 million (2017 Census) is the representative city. Khan et al. reported that daily concentrations of particulate matter with diameters less than $2.5 \mu \mathrm{m}$ $\left(\mathrm{PM}_{2.5}\right)$ approached $177.4 \mu \mathrm{g} \mathrm{m}^{-3}$, averaging levels $4-10$-fold higher than World Health Organization guidelines. ${ }^{35}$ Khwaja et al. revealed sobering morbidity rates among an estimated population of 15 million as a result poor air quality. ${ }^{36}$ These data highlight the urgency of taking immediate measures to address the air pollution problem in Karachi. However, the research still lacks data on the source characteristics of $\mathrm{NO}_{x}$ , and native $\delta^{15} \mathrm{~N}-\mathrm{NO}_{3}{ }^{-}$remains poorly understood at Karachi, and even South Asia (SI Text S3). These deficiencies have limited the ability to enact measures to control indigenous air pollution there. Additionally, Karachi is located on the coast between the Arabian Sea (AS) and South Asian continent (SAC), characterized by sea-land breezes and prevailing northeast and southwest winds. ${ }^{37}$ This makes Karachi, a typical coastal city, susceptible to mixed sources of air pollution, both terrestrial and oceanic in nature.

In response to the insufficient comprehension on the sources of $\mathrm{NO}_{3}{ }^{-}$or $\mathrm{NO}_{x}$ in Karachi, this study conducts a nearly 2 -year sampling of particulate matter. The objectives are to (i) explore the annual, seasonal, and diurnal variations in $\mathrm{NO}_{3}^{-}$, (ii) investigate the sources and conversion features of $\mathrm{NO}_{x}$ using nitrogen/oxygen isotopic analysis $\left(\delta^{15} \mathrm{~N}-\mathrm{NO}_{3}{ }^{-}, \delta^{18} \mathrm{O}-\right.$ $\mathrm{NO}_{3}^{-}$), (iii) quantitatively apportion the year-round $\mathrm{NO}_{x}$ sources relying on a Bayesian mixing model, and (iv) quantify the contribution of oceanic sources to $\mathrm{NO}_{x}$ emissions based on a derivative approach. This study aims to originally reveal the $\delta^{15} \mathrm{~N}-\mathrm{NO}_{3}{ }^{-}$at Karachi in South Asia and to apportion the source of precursory $\mathrm{NO}_{x}$. In addition, the results from this study are expected to pave the way to quantify oceanic sources of $\mathrm{NO}_{x}$ in coastal regions.

\section{MATERIALS AND METHODS}

Sampling Campaign. Sampling of total suspended particulates was conducted in Karachi $\left(24^{\circ} 51^{\prime} \mathrm{N}\right.$; $\left.67^{\circ} 02^{\prime} \mathrm{E}\right)$ from 2 February 2016 to 23 November 2017. The sampling point is on the top floor of an office building of a government agency (about $12 \mathrm{~m}$ in height), which is located in the west of Karachi, on the edge of the main district (SI Figure S1). No agricultural land, but some semiarid bushes, surround it. In addition, there are some government departments gathering here, where no nearby anthropogenic $\mathrm{NO}_{x}$ sources are apparent. Samples were collected using a glass fiber filter and a high-volume sampler (KC-1000, Longtuo) at a flow rate of $1.13 \mathrm{~m}^{3} \mathrm{~min}^{-1}$. The diurnal sampling (12/12 h; day: 10:00 am-22:00 pm; night: 22:00 pm-10:00 am, local time) was carried out once a week every month. In total, 159 samples were collected over the sampling campaign. To minimize contamination, all filters were preheated at $450{ }^{\circ} \mathrm{C}$ for $6 \mathrm{~h}$ in a muffle furnace before sampling. After sampling, the filters were folded and stored in a refrigerator $\left(-20{ }^{\circ} \mathrm{C}\right)$ until further analysis.

The synoptic system in Karachi was dominated by southwest and northeast winds. Here, 70\% (B1:11\% + B2:59\%; SI Figure S2) of the backward trajectories, i.e., from the ocean to the land, originated from the AS; the remaining 30\% (B3) came from the SAC. For the forward trajectories (i.e., from the land to the ocean), $69 \%(\mathrm{~F} 1: 39 \%+\mathrm{F} 2: 30 \%)$ of the air mass continued to move over terrain areas, and 31\% (F3:13\% + F4:18\%) was transferred to the ocean. Such interactions between the land and ocean enable pollutant transfer and exchange, leading to mixed-source air pollution in Karachi.

Chemical and Isotopic Analysis. For $\mathrm{NO}_{3}^{-}$species, briefly, a punch cutout (diameter: $47 \mathrm{~mm}$ ) was removed from the sample collection filter and immersed in Milli-Q water. Samples were extracted ultrasonically for $20 \mathrm{~min}$, and the extracts were filtered. $\mathrm{NO}_{3}{ }^{-}$concentration was measured using an ion chromatograph (Dionex ICS3000, Thermo Fisher Scientific). ${ }^{38}$ The detection limit was $10 \mathrm{ng} \mathrm{mL^{-1 }}$ with less than a $5.2 \%$ error. The nitrous oxide $\left(\mathrm{N}_{2} \mathrm{O}\right)$ isotopic procedure was applied to quantify $\delta^{15} \mathrm{~N}-\mathrm{NO}_{3}{ }^{-}$and $\delta^{18} \mathrm{O}-\mathrm{NO}_{3}{ }^{-}(n=$ 159). ${ }^{39}$ In brief, $\mathrm{NO}_{3}{ }^{-}$extract was diluted to $15 \mu \mathrm{mol} \mathrm{L}{ }^{-1}$ in a $5 \mathrm{~mL}$ solution with $0.5 \mathrm{~mol} \mathrm{~L}^{-1} \mathrm{NaCl}$. Then, $0.3 \mathrm{~g}$ of cadmium powder was added to the solution, and its $\mathrm{pH}$ was adjusted to 9 by injecting $0.1 \mathrm{~mL}$ of imidazole $\left(1 \mathrm{~mol} \mathrm{~L}^{-1}\right)$. Capped tightly with rubber septa, the processed samples were ultrasonically oscillated for $2 \mathrm{~h}$ at $40{ }^{\circ} \mathrm{C}$. In this study, the reduction rate of $\mathrm{NO}_{3}{ }^{-}$to $\mathrm{NO}_{2}^{-}$by cadmium reduction was $97.8 \% \pm 8.3 \%$. After normalizing for $12 \mathrm{~h}, 4 \mathrm{~mL}$ of reacted solution was transferred to a new sample bottle. Sodium azide (1:1 of $20 \%$ acetic acid and sodium azide, purged with helium at $70 \mathrm{~mL}$ $\mathrm{min}^{-1}$ for $10 \mathrm{~min}$ ) was injected for a $30 \mathrm{~min}$ reaction. Finally, the reaction was stopped by $0.4 \mathrm{~mL}$ of $10 \mathrm{~mol} \mathrm{~L}^{-1} \mathrm{NaOH}$. The isotopes $\delta^{15} \mathrm{~N}$ and $\delta^{18} \mathrm{O}$ of $\mathrm{N}_{2} \mathrm{O}$ were analyzed using an isotope ratio mass spectrometer (MAT253, Thermo Fisher Scientific). The values of $\delta^{15} \mathrm{~N}-\mathrm{NO}_{3}{ }^{-}$and $\delta^{18} \mathrm{O}-\mathrm{NO}_{3}{ }^{-}$are reported in parts per thousand relative to the standard guidelines (IAEANO-3, USGS32, USGS34, and USGS35)

$$
\delta^{15} \mathrm{~N}=\left[\left({ }^{15} \mathrm{~N} /{ }^{14} \mathrm{~N}\right)_{\text {sample }} /\left({ }^{15} \mathrm{~N} /{ }^{14} \mathrm{~N}\right)_{\text {standard }}-1\right] \times 1000
$$




$$
\delta^{18} \mathrm{O}=\left[\left({ }^{18} \mathrm{O} /{ }^{16} \mathrm{O}\right)_{\text {sample }} /\left({ }^{18} \mathrm{O} /{ }^{16} \mathrm{O}\right)_{\text {standard }}-1\right] \times 1000
$$

Analytical precision, as calculated using replicates, was less than $0.4 \%$ o for $\delta^{15} \mathrm{~N}-\mathrm{NO}_{3}{ }^{-}$and $0.6 \%$ of $\delta^{18} \mathrm{O}-\mathrm{NO}_{3}{ }^{-}$. The concentrations of $\mathrm{NO}_{2}{ }^{-}$were mostly lower than the detection limit and less than $0.2 \%$ of $\mathrm{NO}_{3}{ }^{-}$, which were ignored during the isotopic analyses. The $\mathrm{NO}_{3}{ }^{-}$concentration for each sample was recalculated by subtracting the average blank value; $\delta^{15} \mathrm{~N}-$ $\mathrm{NO}_{3}{ }^{-}$and $\delta^{18} \mathrm{O}-\mathrm{NO}_{3}{ }^{-}$was determined for each sample by mass balance (SI Text S4).

Monte Carlo Simulation. Monte Carlo simulation refers to a method that uses random or pseudorandom numbers to solve many calculation problems. ${ }^{40}$ Its process is to construct the estimated value of the unknown quantity to be obtained by sampling the random number $x_{i}(i=1,2, \ldots, N)$. The main theoretical basis is the central-limit theorem

$$
\frac{\sqrt{N}\left(\frac{1}{N} \sum_{i=1}^{N} x_{i}-\mu\right)}{\sigma} \sim N(0,1)
$$

where $x_{i}$ is the random number, $\mu$ and $\sigma$ represent the mean and standard deviation, respectively, and $N$ tends to infinity. In this study, the Monte Carlo method was performed to get the feasible solutions of the Bayesian mixing model and the module for qualifying oceanic contributions, respectively.

Bayesian Mixing Model. Source apportionment of $\mathrm{NO}_{x}$ in Karachi was resolved using an improved Bayesian mixing model. Except for the basic Bayesian principle, ${ }^{41}$ this model was perfected by incorporating the isotopic fractionation of the equilibrium/Leighton reaction during the conversion of $\mathrm{NO}_{x}$ to $\mathrm{NO}_{3}{ }^{-}$. Briefly, isotopic fractionation can be regarded as the mixed contribution of two dominative transformations from $\mathrm{NO}$ to $\mathrm{HNO}_{3}$ (neglecting the isotope fractionation from $\mathrm{HNO}_{3}$ to $\left.\mathrm{NO}_{3}^{-}\right)$. ${ }^{32}$ The first transformation is the oxidizing reaction from $\mathrm{NO}$ to $\mathrm{NO}_{2}$ and the reaction from $\mathrm{NO}_{2}$ to $\mathrm{HNO}_{3}$ by photochemically produced $\bullet \mathrm{OH}$, as abbreviated by the $\bullet \mathrm{OH}$ pathway. The second involves the oxidizing reaction from $\mathrm{NO}$ to $\mathrm{NO}_{2}$, an $\mathrm{NO}_{3}$ radical by $\mathrm{O}_{3}$, and the hydrolysis reaction of $\mathrm{N}_{2} \mathrm{O}_{5}$ on a wetted surface to form $\mathrm{HNO}_{3}$, i.e., the $\mathrm{H}_{2} \mathrm{O}$ pathway. Thus, the nitrogen isotopic fractionation contributed by transformation from $\mathrm{NO}$ to $\mathrm{HNO}_{3}$ via both the $\bullet \mathrm{OH}$ and $\mathrm{H}_{2} \mathrm{O}$ pathways can be represented as

$$
\begin{aligned}
& \Delta\left[\delta^{15} \mathrm{~N}-\mathrm{NO}_{3}^{-}\right]=\gamma \times \Delta\left[\delta^{15} \mathrm{~N}-\mathrm{NO}_{3}^{-}\right]_{\mathrm{OH}} \\
& +(1-\gamma) \times \Delta\left[\delta^{15} \mathrm{~N}-\mathrm{NO}_{3}^{-}\right]_{\mathrm{H}_{2} \mathrm{O}}
\end{aligned}
$$

where $\Delta\left[\delta^{15} \mathrm{~N}-\mathrm{NO}_{3}{ }^{-}\right]_{\mathrm{OH}}$ and $\Delta\left[\delta^{15} \mathrm{~N}-\mathrm{NO}_{3}{ }^{-}\right]_{\mathrm{H} 2 \mathrm{O}}$ represent the differences in the nitrogen isotope composition between $\mathrm{HNO}_{3}\left(\mathrm{NO}_{3}^{-}\right)$and $\mathrm{NO}$ caused by the $\bullet \mathrm{OH}$ and $\mathrm{H}_{2} \mathrm{O}$ pathways, respectively. Assuming no kinetic isotopic fractionation associated with the reaction between $\mathrm{NO}_{2}$ and $\bullet \mathrm{OH}$, $\Delta\left(\delta^{15} \mathrm{~N}-\mathrm{HNO}_{3}\right)$ and $\Delta\left(\delta^{15} \mathrm{~N}-\mathrm{HNO}_{3}\right)_{\mathrm{H} 2 \mathrm{O}}$ can be calculated using mass balance, respectively, as follows

$$
\begin{aligned}
& \Delta\left(\delta^{15} \mathrm{~N}-\mathrm{HNO}_{3}\right)_{\mathrm{OH}}=\Delta\left(\delta^{15} \mathrm{~N}-\mathrm{NO}_{2}\right)_{\mathrm{OH}} \\
& \quad=1000 \times\left[\frac{\left({ }^{15} \alpha_{\mathrm{NO}_{2} / \mathrm{NO}}-1\right)\left(1-\mathrm{f}_{\mathrm{NO}_{2}}\right)}{\left(1-\mathrm{f}_{\mathrm{NO}_{2}}\right)+\left({ }^{15} \alpha_{\mathrm{NO}_{2} / \mathrm{NO}} \times \mathrm{f}_{\mathrm{NO}_{2}}\right)}\right] \\
& \Delta\left(\delta^{15} \mathrm{~N}-\mathrm{HNO}_{3}\right)_{\mathrm{H}_{2} \mathrm{O}}=\Delta\left(\delta^{15} \mathrm{~N}-\mathrm{N}_{2} \mathrm{O}_{5}\right)_{\mathrm{H}_{2} \mathrm{O}} \\
& \quad=1000 \times\left({ }^{15} \alpha_{\mathrm{N}_{2} \mathrm{O}_{5} / \mathrm{NO}_{2}}-1\right)
\end{aligned}
$$

where ${ }^{15} \alpha_{\mathrm{NO} 2 / \mathrm{NO}}$ is the equilibrium isotopic fractionation factor between $\mathrm{NO}_{2}$ and $\mathrm{NO}$, and ${ }^{15} \alpha_{\mathrm{N} 2 \mathrm{O} 5 / \mathrm{NO} 2}$ refers to the equilibrium isotopic fractionation factor between $\mathrm{N}_{2} \mathrm{O}_{5}$ and $\mathrm{NO}_{2}$, which are all temperature-dependent functions (eq 10; SI Table S1). ${ }^{31} f_{\mathrm{NO} 2}$ is the fraction of $\mathrm{NO}_{2}$ in the total $\mathrm{NO}_{x}$, typically ranging from 0.2 to $0.95 .^{42} \gamma$ is the contribution of the - OH pathway; its variable range for a specified sample can be assessed by $\delta^{18} \mathrm{O}-\mathrm{NO}_{3}{ }^{-}$in the sample formed by the $\bullet \mathrm{OH}$ and $\mathrm{H}_{2} \mathrm{O}$ pathways

$$
\begin{gathered}
{\left[\delta^{18} \mathrm{O}-\mathrm{NO}_{3}^{-}\right]=\gamma \times\left[\delta^{18} \mathrm{O}-\mathrm{NO}_{3}^{-}\right]_{\mathrm{OH}}} \\
+(1-\gamma) \times\left[\delta^{18} \mathrm{O}-\mathrm{NO}_{3}^{-}\right]_{\mathrm{H}_{2} \mathrm{O}}
\end{gathered}
$$

where $\left[\delta^{18} \mathrm{O}-\mathrm{NO}_{3}{ }^{-}\right]_{\mathrm{OH}}$ and $\left[\delta^{18} \mathrm{O}-\mathrm{NO}_{3}{ }^{-}\right]_{\mathrm{H} 2 \mathrm{O}}$ represent $\delta^{18} \mathrm{O}-\mathrm{NO}_{3}{ }^{-}$formed by the $\bullet \mathrm{OH}$ and $\mathrm{H}_{2} \mathrm{O}$ pathways, respectively. The $\left[\delta^{18} \mathrm{O}-\mathrm{NO}_{3}{ }^{-}\right]_{\mathrm{OH}}$ can be further expressed as ${ }^{32}$

$$
\begin{aligned}
& {\left[\delta^{18} \mathrm{O}-\mathrm{HNO}_{3}\right]_{\mathrm{OH}}=\frac{2}{3}\left[\left(\delta^{18} \mathrm{O}-\mathrm{NO}_{2}\right)\right]_{\mathrm{OH}}+\frac{1}{3}\left[\delta^{18} \mathrm{O}-\mathrm{OH}\right]_{\mathrm{OH}}} \\
& =\frac{2}{3}\left[\frac{1000 \times\left({ }^{18} \alpha_{\mathrm{NO}_{2} / \mathrm{NO}}-1\right)\left(1-f_{\mathrm{NO}_{2}}\right)}{\left(1-f_{\mathrm{NO}_{2}}\right)+\left({ }^{18} \alpha_{\mathrm{NO}_{2} / \mathrm{NO}} \times f_{\mathrm{NO}_{2}}\right)}+\left[\delta^{18} \mathrm{~N}-\mathrm{NO}_{x}\right]\right] \\
& +\frac{1}{3}\left[\left(\delta^{18} \mathrm{O}-\mathrm{H}_{2} \mathrm{O}\right)+1000 \times\left({ }^{18} \alpha_{\mathrm{OH}_{\mathrm{H}} \mathrm{O}}-1\right)\right]
\end{aligned}
$$

and $\left[\delta^{18} \mathrm{O}-\mathrm{NO}_{3}{ }^{-}\right]_{\mathrm{H} 2 \mathrm{O}}$ can be determined as follows

$$
\begin{aligned}
& {\left[\delta^{18} \mathrm{O}-\mathrm{HNO}_{3}\right]_{\mathrm{H}_{2} \mathrm{O}}=\frac{5}{6}\left(\delta^{18} \mathrm{O}-\mathrm{N}_{2} \mathrm{O}_{5}\right)} \\
& +\frac{1}{6}\left(\delta^{18} \mathrm{O}-\mathrm{H}_{2} \mathrm{O}\right)
\end{aligned}
$$

where ${ }^{18} \alpha_{\mathrm{NO} 2 / \mathrm{NO}}$ and ${ }^{18} \alpha_{\mathrm{OH} / \mathrm{H} 2 \mathrm{O}}$ are the equilibrium isotope fractionation factors between $\mathrm{NO}_{2}$ and $\mathrm{NO}$, and $\bullet \mathrm{OH}$ and $\mathrm{H}_{2} \mathrm{O}$, respectively, which are temperature-dependent functions (SI Table S1).

$$
\begin{aligned}
& 1000\left({ }^{\mathrm{m}} \alpha_{\mathrm{X} / \mathrm{Y}}-1\right)=\frac{\mathrm{A}}{\mathrm{T}^{4}} \times 10^{10}+\frac{\mathrm{B}}{\mathrm{T}^{3}} \times 10^{8} \\
& +\frac{\mathrm{C}}{\mathrm{T}^{2}} \times 10^{6}+\frac{\mathrm{D}}{\mathrm{T}} \times 10^{4}
\end{aligned}
$$

On the basis of the computing theory, a Monte Carlo simulation was performed to generate 10,000 feasible solutions, which determined that the error between predicted and measured $\delta^{18} \mathrm{O}$ was less than $0.5 \%$. For the particular model framework and computing method, readers are referred to Zong et al. ${ }^{43}$

In this study, coal combustion $(+13.7 \pm 4.6 \% 0))^{25,44}$ biomass burning + lightning $(+0.9 \pm 3.9 \% 0),{ }^{18,26}$ mobile sources $(-7.2 \pm 7.4 \% 0)^{28,29,44,45}$ and microbial processes $(-35.4 \pm 10.7 \% \text { o })^{27,30,46,47}$ were considered end members in our Bayesian simulation (SI Text S5; Figure S3; Table S2). The Bayesian mixing model was run for four patterns, specifically as overall, seasonal, monthly, and clustering simulations, to investigate the comprehensive $\mathrm{NO}_{x}$ sources in Karachi.

Module for Qualifying Oceanic Contributions. To distinguish the oceanic contribution from Bayesian modeling source apportionment, this model was further modified by adding a module for sample sectionalization and an analytical module (Figure 1). The grouping module was divided into several sample subgroups according to the cluster data of the backward trajectories operated by the HYSPLIT model. The 


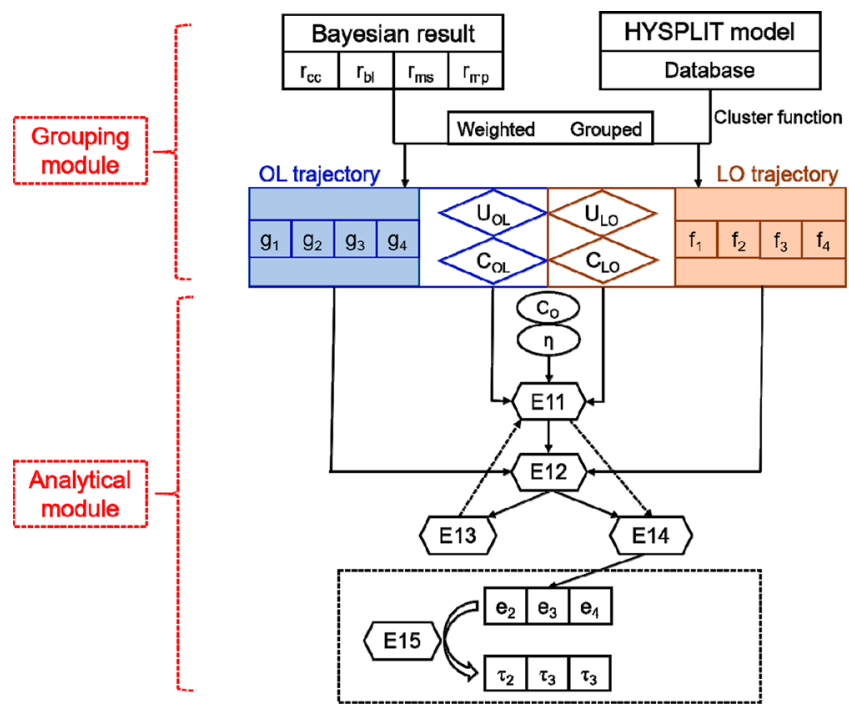

Figure 1. Principle and process of the calculation for oceanic $\mathrm{NO}_{x}$ sources in this study; $r_{i}$ refers to the contribution proportion of $i$ source from the Bayesian result (cc: coal combustion; bl: biomass burning + lightning; ms: mobile sources; mp: microbial processes); E11-E15 represents formulas 11-15, respectively; other parameters are consistent with their meaning in the text.

HYSPLIT model is a complete system for computing simple air parcel trajectories to complex dispersion simulation. ${ }^{48}$ It is available on the National Oceanic and Atmospheric Administration Air Resource Laboratory website (www.arl.noaa.gov/ ready/hysplit4.html). In this study, the model was adopted to generate $72 \mathrm{~h}$ forward and backward trajectories encountered $(500 \mathrm{~m})$ with $6 \mathrm{~h}$ intervals at Karachi (SI Text 6). The obtained 318 trajectories were then bunched into clusters by the clustering function of this model. In Karachi, there are four trajectories related to ocean areas (SI Figure S2): two backward trajectories from the ocean to the land (B1 and $\mathrm{B} 2$, referred to as the OL trajectory) and two forward trajectories from the land to the ocean (F3 and F4, the LO trajectory). Source contributions from the four Bayesian scenarios were weighted to distinguish the oceanic contribution in subsequent analytical modules.

On the basis of the terrestrial source nature of $\mathrm{NO}_{3}{ }^{-}$in the OL trajectory in Karachi (SI Text S7), the $\mathrm{NO}_{3}{ }^{-}$flux of the $\mathrm{OL}$ trajectory is approximately equal to the product of the sum of the concentration of $\mathrm{NO}_{3}{ }^{-}$in the $\mathrm{LO}$ trajectory undergoing removal processes (e.g., atmospheric deposition) and the concentration of $\mathrm{NO}_{3}^{-}$originating from the ocean and the corresponding wind speed

$$
\mathrm{F}_{\mathrm{OL}}=\mathrm{U}_{\mathrm{OL}} \mathrm{C}_{\mathrm{OL}}=\mathrm{U}_{\mathrm{LO}}\left[(1-\eta) \mathrm{C}_{\mathrm{LO}}+\mathrm{C}_{\mathrm{O}}\right]
$$

where $\mathrm{F}_{\mathrm{OL}}, \mathrm{U}_{\mathrm{OL}}$, and $\mathrm{C}_{\mathrm{OL}}$ represent the flux of $\mathrm{NO}_{3}{ }^{-}$, the wind speed, and the concentration of $\mathrm{NO}_{3}{ }^{-}$in the OL trajectory, respectively. $\mathrm{U}_{\mathrm{LO}}$ and $\mathrm{C}_{\mathrm{LO}}$ refer to the wind speed and the concentration of $\mathrm{NO}_{3}{ }^{-}$in the $\mathrm{LO}$ trajectory, respectively. $\eta$ is the removal efficiency of $\mathrm{NO}_{3}{ }^{-}$from the atmosphere, and $\mathrm{C}_{\mathrm{O}}$ is the concentration of $\mathrm{NO}_{3}{ }^{-}$emitted by the ocean. According to the results of the Bayesian model, we can resolve the contributions of the four types of emission sources (coal combustion, biomass combustion + lightning, mobile sources, and microbial processes) into $\mathrm{C}_{\mathrm{OL}}$ and $\mathrm{C}_{\mathrm{LO}}$. Of these, only coal combustion shows a pure terrestrial nature; thus, its oceanic contribution would be zero. Equation 11 can be decomposed into the following

$$
\begin{aligned}
& \mathrm{F}_{\mathrm{OL}}(\mathrm{C})=\mathrm{U}_{\mathrm{OL}} \mathrm{C}_{\mathrm{OL}} \mathrm{g}_{1}=\mathrm{U}_{\mathrm{LO}}(1-\eta) \mathrm{C}_{\mathrm{LO}} \mathrm{f}_{1} \\
& \mathrm{~F}_{\mathrm{OL}}(\mathrm{B})=\mathrm{U}_{\mathrm{OL}} \mathrm{C}_{\mathrm{OL}} \mathrm{g}_{2}=\mathrm{U}_{\mathrm{LO}}\left[(1-\eta) \mathrm{C}_{\mathrm{LO}_{2}} \mathrm{f}_{2}+\mathrm{C}_{\mathrm{O}} \mathrm{e}_{2}\right] \\
& \mathrm{F}_{\mathrm{OL}}(\mathrm{T})=\mathrm{U}_{\mathrm{OL}} \mathrm{C}_{\mathrm{OL}} \mathrm{g}_{3}=\mathrm{U}_{\mathrm{LO}}\left[(1-\eta) \mathrm{C}_{\mathrm{LO}_{3}} \mathrm{f}_{3}+\mathrm{C}_{\mathrm{O}} \mathrm{e}_{3}\right] \\
& \mathrm{F}_{\mathrm{OL}}(\mathrm{V})=\mathrm{U}_{\mathrm{OL}} \mathrm{C}_{\mathrm{OL}} \mathrm{g}_{4}=\mathrm{U}_{\mathrm{LO}}\left[(1-\eta) \mathrm{C}_{\mathrm{LO}_{4}} \mathrm{f}_{4}+\mathrm{C}_{\mathrm{O}} \mathrm{e}_{4}\right]
\end{aligned}
$$

where $\mathrm{F}_{\mathrm{OL}}(\mathrm{C}), \mathrm{F}_{\mathrm{OL}}(\mathrm{B}), \mathrm{F}_{\mathrm{OL}}(\mathrm{T})$, and $\mathrm{F}_{\mathrm{OL}}(\mathrm{V})$ refer to the $\mathrm{NO}_{3}{ }^{-}$ flux contributed by coal combustion, biomass combustion + lightning, mobile sources, and microbial processes, respectively, in the OL trajectory; $\mathrm{g}_{1}, \mathrm{~g}_{2}, \mathrm{~g}_{3}$, and $\mathrm{g}_{4}$ are the contribution ratios for coal combustion, biomass combustion + lightning, mobile sources, and microbial processes, respectively, in the OL trajectory; $\mathrm{f}_{1}, \mathrm{f}_{2}, \mathrm{f}_{3}$, and $\mathrm{f}_{4}$ are the contribution ratios for coal combustion, mobile sources, biomass combustion + lightning, and microbial processes, respectively, in the LO trajectory; and $\mathrm{e}_{2}, \mathrm{e}_{3}$, and $\mathrm{e}_{4}$ refer to the contribution ratios of biomass combustion + lightning, mobile sources, and microbial processes from marine sources, respectively. In light of the pure terrestrial nature of coal combustion, the parameter $\eta$ can be transformed into

$$
\eta=1-\frac{\mathrm{U}_{\mathrm{OL}} \mathrm{C}_{\mathrm{OL}} \mathrm{g}_{1}}{\mathrm{U}_{\mathrm{LO}} \mathrm{C}_{\mathrm{LO}} \mathrm{f}_{1}}
$$

From the formulas given, $\mathrm{C}_{\mathrm{O}}, \mathrm{e}_{2}, \mathrm{e}_{3}$, and $\mathrm{e}_{4}$, are given by

$$
\begin{aligned}
\mathrm{C}_{\mathrm{O}} & =\left(1-\frac{\mathrm{g}_{1}}{\mathrm{f}_{1}}\right) \frac{\mathrm{U}_{\mathrm{OL}} \mathrm{C}_{\mathrm{OL}}}{\mathrm{U}_{\mathrm{LO}}} \\
\mathrm{e}_{2} & =\left(\mathrm{g}_{2}-\frac{\mathrm{g}_{1}}{\mathrm{f}_{1}} \mathrm{f}_{2}\right) /\left(1-\frac{g_{1}}{\mathrm{f}_{1}}\right) \\
\mathrm{e}_{3} & =\left(\mathrm{g}_{3}-\frac{\mathrm{g}_{1}}{\mathrm{f}_{1}} \mathrm{f}_{3}\right) /\left(1-\frac{\mathrm{g}_{1}}{\mathrm{f}_{1}}\right) \\
\mathrm{e}_{4} & =\left(\mathrm{g}_{4}-\frac{\mathrm{g}_{1}}{\mathrm{f}_{1}} \mathrm{f}_{4}\right) /\left(1-\frac{\mathrm{g}_{1}}{\mathrm{f}_{1}}\right)
\end{aligned}
$$

The formulas can be further used to calculate the contributions of biomass combustion + lightning $\left(\tau_{2}\right)$, mobile sources $\left(\tau_{3}\right)$, microbial processes $\left(\tau_{4}\right)$, and their sum $\left(\tau_{\mathrm{T}}\right)$

$$
\begin{aligned}
& \tau_{\mathrm{T}}=\frac{\mathrm{C}_{\mathrm{O}}}{\mathrm{C}_{\mathrm{OL}}}=\left(1-\frac{g_{1}}{f_{1}}\right) \frac{\mathrm{U}_{\mathrm{OL}}}{\mathrm{U}_{\mathrm{LO}}} \\
& \tau_{2}=\left(g_{2}-\frac{g_{1} f_{2}}{f_{1}}\right) \frac{\mathrm{U}_{\mathrm{OL}}}{\mathrm{U}_{\mathrm{LO}}} \\
& \tau_{3}=\left(g_{3}-\frac{g_{1} f_{3}}{f_{1}}\right) \frac{\mathrm{U}_{\mathrm{OL}}}{\mathrm{U}_{\mathrm{LO}}} \\
& \tau_{4}=\left(g_{4}-\frac{g_{1} f_{4}}{f_{1}}\right) \frac{\mathrm{U}_{\mathrm{OL}}}{\mathrm{U}_{\mathrm{LO}}}
\end{aligned}
$$

It is noted that the mean values and the associated standard deviations (mean \pm SD) were employed consistently throughout the modeling operation. Arithmetically, a Monte Carlo simulation was performed to generate 10,000 feasible 

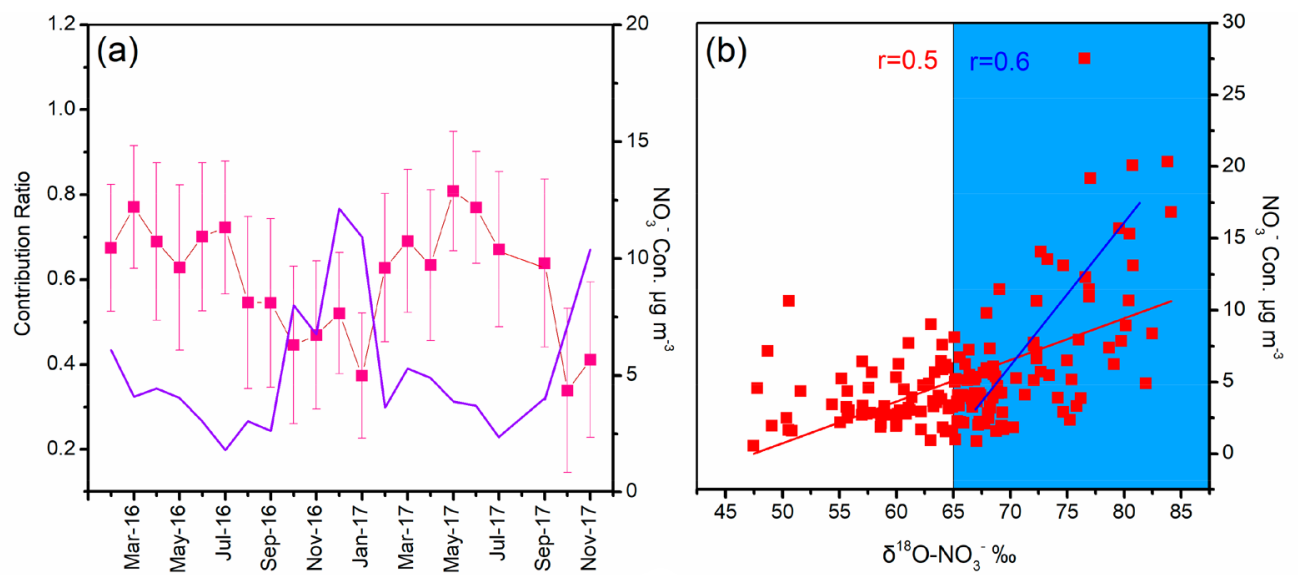

Figure 2. (a) Relationship between calculated $\bullet \mathrm{OH}$ pathway ratio (pink box; mean \pm standard) and $\mathrm{NO}_{3}{ }^{-}$concentration (purple line). (b) Correlation coefficients between $\delta^{18} \mathrm{O}-\mathrm{NO}_{3}{ }^{-}$and $\mathrm{NO}_{3}{ }^{-}$concentration (overall correlation and correlation when limiting $\delta^{18} \mathrm{O}-\mathrm{NO}_{3}{ }^{-}$to $+65 \% 0$ or more).

solutions (SI Figure S4), and an iterative model with a simulation step of 0.01 was applied to achieve optimal results. ${ }^{49}$

\section{RESULTS AND DISCUSSION}

Concentration Regime and Source Feature Based on $\delta^{15} \mathrm{~N}-\mathrm{NO}_{3}{ }^{-}$. From February 2016 to November 2017, the concentration of $\mathrm{NO}_{3}^{-}$ranged from 0.6 to $27.5 \mu \mathrm{g} \mathrm{m}^{-3}$ in Karachi, with a mean value of $5.4 \pm 4.1 \mu \mathrm{g} \mathrm{m}^{-3}$. Compared with previous studies, our results indicated an increase in the $\mathrm{NO}_{3}{ }^{-}$concentration, which was attributed to population expansion and enhanced energy consumption. ${ }^{50,51}$ The daytime concentration $\left(5.8 \pm 4.7 \mu \mathrm{g} \mathrm{m}^{-3}\right)$ was comparable to the concentration at night $\left(5.2 \pm 3.2 \mu \mathrm{g} \mathrm{m}^{-3}\right)$ with no significant difference. However, a distinct seasonal variation was observed, with higher values $(p<0.01)$ in the autumn and winter (average: $7.1 \pm 5.1 \mu \mathrm{g} \mathrm{m}^{-3}$ ) and lower values in summer and spring (average: $3.9 \pm 2.0 \mu \mathrm{g} \mathrm{m}^{-3}$ ). Specifically, the highest concentrations occurred in November, December, and January, and the lowest values in June, July, and August (SI Figure S5; Table S3). Annually, the second study year exhibited higher values than the first, which is consistent with the worsening trend of pollution in South Asia. ${ }^{52}$

Pollutant concentrations are generally governed by meteorological conditions and emission sources. ${ }^{53}$ The temperature and relative humidity shared an insignificant correlation with $\mathrm{NO}_{3}{ }^{-}$concentrations, indicating a weak impact of these meteorological parameters on the variation of $\mathrm{NO}_{3}{ }^{-}$. Nonetheless, the $\mathrm{NO}_{3}{ }^{-}$concentrations were positively correlated with wind speed, with $\mathrm{r}$ of $0.5(p<0.05)$. It suggests that the influence of wind speed was stronger than other meteorological parameters. In addition, $\delta^{15} \mathrm{~N}-\mathrm{NO}_{3}{ }^{-}$reflected the changing character of potential $\mathrm{NO}_{x}$ source types. During the observing period, $\delta^{15} \mathrm{~N}-\mathrm{NO}_{3}{ }^{-}$varied between $-10.2 \% 0$ and $+12.4 \%$, with a mean value of $+1.8 \pm 4.5 \%$ o (SI Figure S6). Compared with the readings obtained at night $(+1.4 \pm 4.0 \%$ ), there is no significant difference in the value of $\delta^{15} \mathrm{~N}-\mathrm{NO}_{3}{ }^{-}$for the daytime $(+2.1 \pm 4.9 \%$; $p>0.05)$, similar to the stable tendency of the $\mathrm{NO}_{3}{ }^{-}$concentration. In autumn and winter, the average $\delta^{15} \mathrm{~N}-\mathrm{NO}_{3}{ }^{-}$reading was $+3.1 \pm 3.9 \%$, which was significantly higher $(p<0.01)$ than that for spring and summer $(-0.2 \pm 3.1 \%$ o $)$. Atmospheric $\mathrm{NO}_{3}{ }^{-}$is derived mainly from the oxidation of $\mathrm{NO}_{x}$, whereas the $\delta^{15} \mathrm{~N}-\mathrm{NO}_{x}$ from different anthropogenic or natural sources shows great variability. ${ }^{26,30}$ For example, $\mathrm{NO}_{x}$ from coal combustion has a higher ${ }^{15} \mathrm{~N}$ value $(+13.7 \pm 4.6 \% 0),{ }^{25}$ whereas $\delta^{15} \mathrm{~N}-\mathrm{NO}_{x}$ from microbial processes is often negative $(-35.4 \pm 10.7 \% 0) .{ }^{27}$ Despite the ${ }^{15} \mathrm{~N}$ isotopic fractionation that occurs in the conversion of $\mathrm{NO}_{x}$ to $\mathrm{NO}_{3}{ }^{-}$, a previous study has indicated that $\mathrm{NO}_{x}$ sources can be identified based on the $\delta^{15} \mathrm{~N}-\mathrm{NO}_{3}{ }^{-}$value. ${ }^{54}$ In this study, we corrected the corresponding $\delta^{15} \mathrm{~N}-\mathrm{NO}_{x}$ by removing the potential isotopic fractionation (SI Figure S6), manifesting a parallel trend with $\delta^{15} \mathrm{~N}-\mathrm{NO}_{3}{ }^{-}$. As such, the observed variation in $\delta^{15} \mathrm{~N}-\mathrm{NO}_{3}{ }^{-}$at Karachi can be linked to an increase in coal combustion in the autumn and winter and to microbial processes in the spring and summer, which could be further verified by the subsequent results of the Bayesian model.

Formation Pathway of $\mathrm{NO}_{x}$ Inferred from $\delta^{18} \mathrm{O}-\mathrm{NO}_{3}{ }^{-}$. In the atmosphere, the main conversion processes of $\mathrm{NO}_{x}$ to $\mathrm{NO}_{3}{ }^{-}\left(\mathrm{SI} \mathrm{SR}_{1}-\mathrm{SR}_{8}\right)$ include the $\bullet \mathrm{OH}$ pathway $\left(\mathrm{SI} \mathrm{SR}_{4}\right)$ and $\mathrm{O}_{3}$ pathway $\left(\mathrm{SI} \mathrm{SR} \mathrm{SR}_{5}-\mathrm{SR}_{7}\right.$ ). Thus, $\delta^{18} \mathrm{O}-\mathrm{NO}_{3}{ }^{-}$can be used to determine $\mathrm{NO}_{x}$ conversion trends, given that the reported $\delta^{18} \mathrm{O}-\mathrm{H}_{2} \mathrm{O}$ readings ranged from $-25 \%$ to $0 \%$, showing a significant difference with respect to $\delta^{18} \mathrm{O}-\mathrm{O}_{3}$ readings $(+90 \%$ to $+122 \% 0){ }^{3}$ The $\mathrm{HC} / \mathrm{DMS}$ pathway $\left(\mathrm{NO}_{3}+\right.$ DMS/HC reactions) is also an important conversion pathway of $\mathrm{NO}_{x}$ to $\mathrm{NO}_{3}{ }^{-}$, especially in the high latitudes in the marine boundary layer. ${ }^{55}$ Limited to the lack of $\Delta^{17} \mathrm{O}$ data, its proportion in the $\mathrm{NO}_{x}$ conversion could not be quantified here. However, its contribution should be small due to the geographical location of Karachi (SI Figure S7). ${ }^{56}$ Therefore, this pathway was ignored in this study, which may cause some uncertainty to the result. In Karachi, the average for $\delta^{18} \mathrm{O}-$ $\mathrm{NO}_{3}{ }^{-}$was $+66.2 \pm 7.8 \%$, ranging from $+47.5 \%$ o to $+84.1 \%$ o (SI Figure S8), well within the broad range of values reported previously. ${ }^{11,57}$ Thus, the results revealed a seasonal trend, with higher $(p<0.05)$ values in autumn and winter (average: +69.0 $\pm 8.6 \%$ ) than in spring and summer (average: $+63.6 \pm$ $5.7 \%$ ); this suggests the prevalence of the $\mathrm{O}_{3}$ pathway in cold seasons. Unlike the results from other studies, ${ }^{38}$ no significant diurnal variation in $\delta^{18} \mathrm{O}-\mathrm{NO}_{3}{ }^{-}$was observed $(p>0.05,+$ $65.6 \pm 10.1 \%$ and $+66.6 \pm 7.8 \%$ during the day and at night, respectively), indicating no obvious change in the $\mathrm{NO}_{3}{ }^{-}$ 


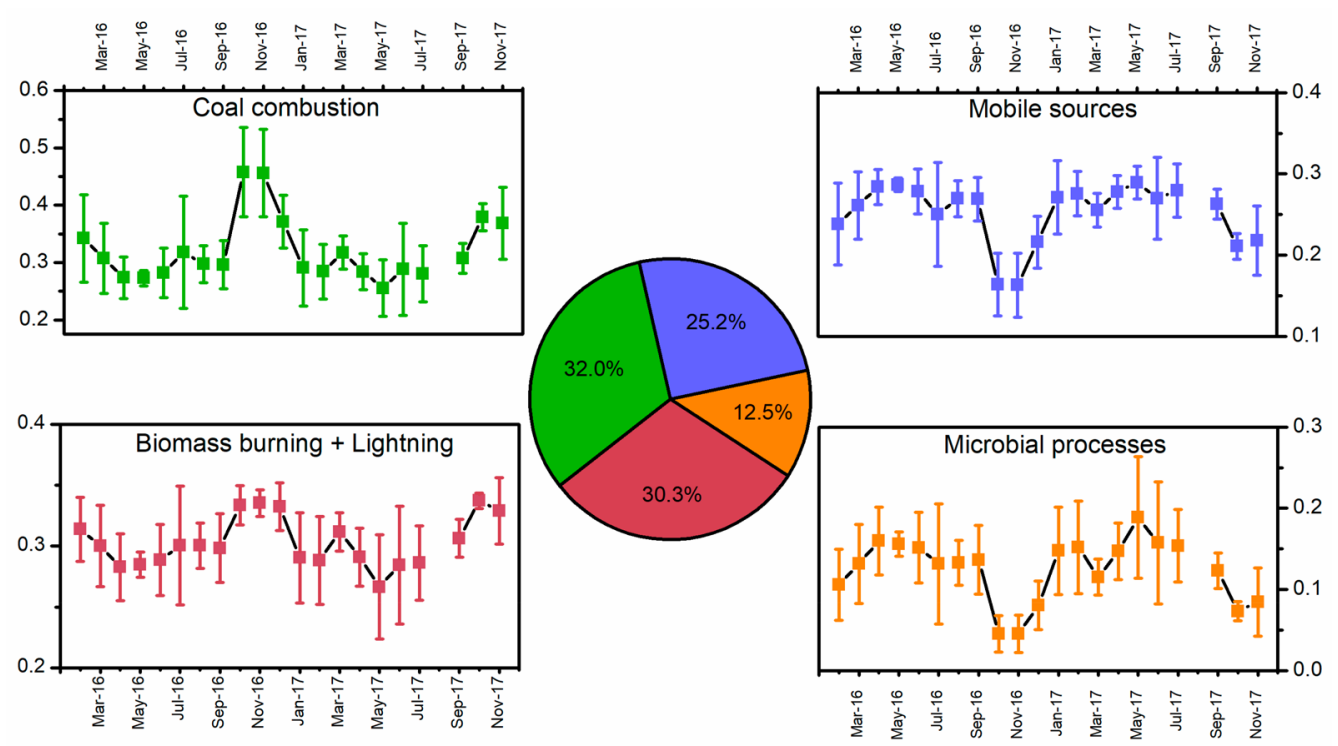

Figure 3. Contributions of coal combustion, mobile sources, biomass burning + lightning and microbial processes to $\mathrm{NO}_{x}$ at Karachi.

generation pathway over the course of a 24 -h period. This may be related to the high average temperature $\left(27.1 \pm 4.2{ }^{\circ} \mathrm{C}\right)$ throughout the study period, showing only slight diurnal variation. For the $\mathrm{O}_{3}$ pathway, nitrogen pentoxide $\left(\mathrm{N}_{2} \mathrm{O}_{5}\right.$; SI $\mathrm{SR}_{6}$ ) is the key intermediate; its thermolabile character reduced the influence of the $\mathrm{O}_{3}$ pathway during the nighttime hours in this study compared with results previously reported. $^{58}$

To further quantify the ratio of the two $\mathrm{NO}_{x}$ conversion processes, we applied certain assumptions ( $2 / 3$ of oxygen atoms in $\mathrm{NO}_{3}{ }^{-}$are from $\mathrm{O}_{3}$ and $1 / 3$ from $\bullet \mathrm{OH}$ in the $\bullet \mathrm{OH}$ pathway, and $5 / 6$ of oxygen atoms are from $\mathrm{O}_{3}$ and $1 / 6$ from $\bullet \mathrm{OH}$ in the $\mathrm{O}_{3}$ pathway) to the Bayesian mixing model and estimated the respective ratio using a Monte Carlo simulation. ${ }^{3}$ The mean and standard deviations of the contribution for the - OH pathway are presented in Figure 2(a). Overall, the wide range $(20.3 \%-94.9 \%)$ was due to the broad range of $\delta^{18} \mathrm{O}-\mathrm{O}_{3}$ $(+90 \%$ to $+122 \% 0)$ and $\delta^{18} \mathrm{O}-\bullet \mathrm{OH}$ values $(-25 \%$ to $0 \%$ ) used; however, the mean values showed distinct seasonal fluctuations. The average contribution of the $\bullet \mathrm{OH}$ pathway in autumn and winter was $52.1 \pm 28.4 \%$ and that in spring and summer was $69.9 \pm 14.2 \%$. Thus, the proportion of the $\bullet \mathrm{OH}$ pathway in autumn and winter was about $17.8 \%$ lower than that in the spring and summer when the $\bullet \mathrm{OH}$ conversion pathway was absolutely dominant. No significant diurnal variation was observed, with contributions of $62.0 \pm 21.4 \%$ in the daytime and $60.5 \pm 22.5 \%$ at night. These values were both consistent with $\delta^{18} \mathrm{O}-\mathrm{NO}_{3}^{-}$trends discussed earlier. In addition, the $\bullet \mathrm{OH}$ pathway proportion showed a strong negative correlation with $\mathrm{NO}_{3}{ }^{-}$concentration $(\mathrm{r}=0.6, p<$ 0.01). This implies that $\mathrm{O}_{3}$ may be the major contributing factor to high $\mathrm{NO}_{3}{ }^{-}$concentrations in Karachi, as further indicated by the correlation coefficient between $\delta^{18} \mathrm{O}-\mathrm{NO}_{3}{ }^{-}$ and the $\mathrm{NO}_{3}{ }^{-}$concentration (Figure 2b). ${ }^{59}$ The correlation coefficient was 0.5 but increased to 0.6 , limiting $\delta^{18} \mathrm{O}-\mathrm{NO}_{3}{ }^{-}$ to $+65 \%$ or more. $\delta^{18} \mathrm{O}-\mathrm{O}_{3}$ ranged from $+90 \%$ to $+122 \%$; higher $\delta^{18} \mathrm{O}-\mathrm{NO}_{3}^{-}$values denote a stronger effect by $\mathrm{O}_{3}$. Thus, we can conclude that although the $\bullet \mathrm{OH}$ pathway dominated the $\mathrm{NO}_{x}$ conversion in Karachi, the high $\mathrm{NO}_{3}{ }^{-}$ concentration indicates a strong effect related to the $\mathrm{O}_{3}$ pathway. Thus, controlling $\mathrm{O}_{3}$ emissions may be an effective measure to reduce the indigenous occurrence of high pollution events. 60

Source Apportionment of $\mathrm{NO}_{x}$ Based on the Bayesian Mixing Model. The overall simulation results showed that coal combustion was the most significant source $(32.0 \pm 9.8 \%)$ of $\mathrm{NO}_{x}$ in Karachi, followed by biomass burning + lightning $(30.3 \pm 6.5 \%)$, mobile sources $(25.2 \pm 6.4 \%)$, and microbial processes $(12.5 \pm 7.5 \%)$. These findings are consistent with Karachi's characteristic forms of energy consumption. ${ }^{61}$ To our knowledge, no studies have been conducted on the analysis of $\mathrm{NO}_{3}{ }^{-}$or $\mathrm{NO}_{x}$ using nitrogen isotopes in South Asia (SI Text S3), which greatly hinder the regional comparison. Therefore, this study selects Beijing, one of the most polluted megacity cities in China, as a comparison object to further analyze the source characteristics of $\mathrm{NO}_{x}$ at Karachi. The comparison between the two cities could reflect the pollution status of China and Pakistan, in East Asia and South Asia, respectively. Compared with Beijing [evaluated by the same method: coal combustion $(40.5 \pm 12.3 \%)$, biomass burning $(21.5 \pm 5.8 \%)$, vehicle exhausts $(24.1 \pm 3.8 \%)$, and the microbial $\mathrm{N}$ cycle $(14.0 \pm 7.5 \%)]$, the contributions of coal combustion and microbial processes were lower (SI Figure S9); however, mobile sources and biomass burning + lightning were higher. Although Karachi is a megacity, biomass is the main contributor to $\mathrm{NO}_{x}$ emissions in slum areas located throughout the city. Alam et al. reported that household combustion emission comprised mainly biomass burning, an important contributor to $\mathrm{PM}_{10}$ in Pakistan. ${ }^{62}$ In Lahore and Karachi, biomass and coal combustion have been shown to contribute greatly to secondary aerosol formation, especially $\mathrm{NO}_{3}{ }^{-}$and $\mathrm{SO}_{4}{ }^{2-} \cdot{ }^{63,64}$ In another study, 24-h levoglucosan analysis indicated an average reading of $535 \mathrm{ng} \mathrm{m}^{-3}$ in Karachi from the burning of various hardwoods and softwoods. ${ }^{35}$ In addition, Chen et al. reported that lightning sources contributed up to $56 \%$ of the $\mathrm{NO}_{3}{ }^{-}$emissions in wet deposition in Zhanjiang, a tropical city in China with a similar latitude to Karachi (far below Beijing). ${ }^{65}$ Hence, together with the factor of latitude, biomass burning + lightning is a significant source of $\mathrm{NO}_{x}$ in Karachi. Although car ownership in Beijing reached 6 million in 2018, according to Chinese car industry surveys (higher than that in Karachi, at 3.6 million), 
the emission standards (National IV Standard) are much lower than those in Karachi (European II standard), which means that the level of pollutant gases (e.g., $\mathrm{NO}_{x}, \mathrm{SO}_{2}$ ) emitted by each vehicle is lower. ${ }^{66}$ In addition, Karachi serves as a transportation hub and is home to Pakistan's two largest ports. Thus, shipping contributes a large portion of the emissions, ${ }^{67}$ as evidenced by the results quantifying oceanic source contributions, with shipping emissions at $7.8 \%$; this is discussed in the next section.

Karachi is home to $47 \%$ of Pakistan's industries; the major state-owned plants include Pakistani steel mills, the Karachi shipyard, and two oil refineries that consume large amounts of coal. In 2016, coal consumption in Pakistan was about 20 million tons. ${ }^{68}$ However, the consumption was significantly lower than that in China (4.4 billion tons). ${ }^{69}$ Although China's coal $\mathrm{NO}_{x}$ emissions have shown a downward trend due to the widespread installation of pollution control equipment, its $\mathrm{NO}_{x}$ emissions due to coal are still much higher than Pakistan's. ${ }^{70}$ Furthermore, $\mathrm{NO}_{x}$ emissions are mainly concentrated in North China near Beijing and are prominent in winter due to residential coal burning. ${ }^{71}$ Beijing is located on the northern edge of the North China Plain $\left(1.3 \times 10^{6} \mathrm{~km}^{2}\right)$ with climatic rain and heat periods; this large agricultural area receives large amounts of nitrate fertilizer and is susceptible to fertilizer misuse. $^{72}$ Thus, a location such as this could be a significant microbial emission source. Illustratively, the $\mathrm{NO}_{x}$ contribution of this source in summer can reach about $20.8 \%$ in Beijing. In contrast, the subtropical climate around Karachi, which is almost desert-like most of the year, limits microorganism activity in this region although there are several wetland parks. These combined factors lead to the relatively lower contribution of coal combustion and microbial processes in Karachi.

Figure 3 also shows the seasonal variation in contributions from the four sources. Coal combustion exhibited the most obvious fluctuation, with a greater contribution in autumn and winter $(35.5 \pm 5.5 \%)$ and a smaller one in spring and summer $(28.9 \pm 4.8 \%)$. Biomass burning + lightning contribution changed somewhat, with high values recorded in autumn and winter. Mobile sources and microbial processes were consistent in contribution variation, showing seasonal change opposite the trends for the first two sources. Specifically, coal combustion and biomass burning + lightning peaked in October, November, and December. This was about a month before high concentrations of $\mathrm{NO}_{3}{ }^{-}$appeared, indicating that the two sources, especially coal combustion, led to the occurrence of high $\mathrm{NO}_{3}{ }^{-}$pollution in Karachi. This is consistent with the source characteristics indicated by $\delta^{15} \mathrm{~N}-$ $\mathrm{NO}_{3}{ }^{-}$findings discussed earlier. The sharp increases in coal combustion and biomass burning + lightning were in agreement with the changes in local energy demand and wind direction (SI Text S8; Figure S10), resulting in conspicuous reductions in the importance of the other two sources. $^{73}$ It is possible, of course, that the emission equivalents of the mobile sources and microbial processes did not change significantly; however, the corresponding $\mathrm{NO}_{x}$ concentrations in Karachi were not resolved in this study.

Estimation of Oceanic Contributions to $\mathrm{NO}_{x}$. The oceanic contributions of $\mathrm{NO}_{x}$ in Karachi are still not well understood, which complicates efforts to control the air pollution in this area. ${ }^{74}$ In this study, four trajectories were related to the AS region: two trajectories from land areas to the ocean (LO trajectory) and two from the ocean to the land (OL trajectory) (SI Figure S2). The trajectories were clustered based on the airflow trajectories over the entire sampling period, representing the interaction characteristics of the wind field between the land and the ocean. ${ }^{48}$ As a whole, oceandominated air masses accounted for $69 \%$ of the total contribution, whereas $31 \%$ was due to a terrestrial trajectory.

The $\mathrm{NO}_{3}{ }^{-}$information was grouped based on the clustered trajectories (Figure 4). Mean test results indicated that the

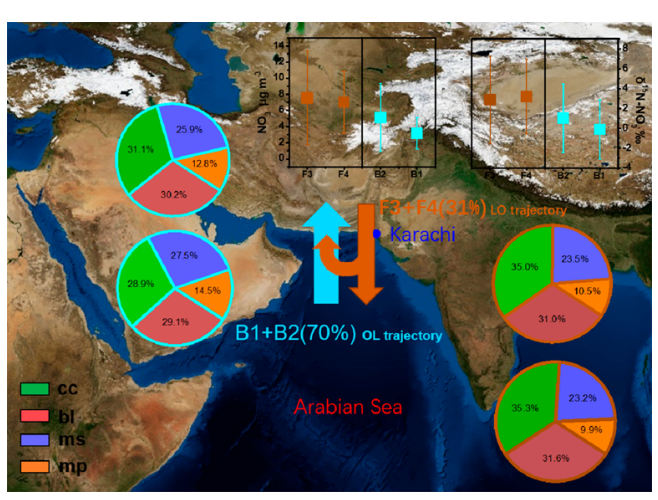

Figure 4. Characteristics of $\mathrm{LO}$ trajectory and $\mathrm{OL}$ trajectory for $\mathrm{NO}_{3}{ }^{-}$ at Karachi: "F" is the forward trajectory clusters (LO trajectory), and "B" refers to the backward trajectory clusters ( $\mathrm{OL}$ trajectory). cc, bl, $\mathrm{ms}$, and $\mathrm{mp}$ represent the source of coal combustion, biomass burning + lightning, mobile sources, microbial processes, respectively.

$\mathrm{NO}_{3}{ }^{-}$concentration differed significantly between the $\mathrm{OL}$ trajectory $\left(\mathrm{B} 1: 3.2 \pm 2.0 \mu \mathrm{g} \mathrm{m}^{-3}, \mathrm{~B} 2: 5.2 \pm 4.2 \mu \mathrm{g} \mathrm{m}^{-3}\right)$ and the LO trajectory $\left(\mathrm{F} 3: 7.6 \pm 5.8 \mu \mathrm{g} \mathrm{m}^{-3}, \mathrm{~F} 4: 7.0 \pm 3.8 \mu \mathrm{g} \mathrm{m}^{-3}\right)$; the OL concentration was markedly higher than the LO concentration $(p<0.01)$, perhaps due to the dilution of the $\mathrm{OL}$ trajectory possessing a greater proportion. $\delta^{15} \mathrm{~N}-\mathrm{NO}_{3}{ }^{-}$ was $+2.9 \pm 4.4 \%$ and $+3.2 \pm 3.8 \%$ in $\mathrm{F} 3$ and $\mathrm{F} 4$, respectively, both of which were higher $(p<0.05)$ than the corresponding oceanic values of $-0.1 \pm 3.0 \%$ in $\mathrm{B} 1$ and $+1.0 \pm 3.5 \%$ in $\mathrm{B} 2$. In terms of the isotopic distributions of different sources, the contribution of coal combustion for $\mathrm{NO}_{x}$ in the LO trajectory was more obvious, consistent with its terrestrial nature. ${ }^{39}$ Quantitatively, the contributions of coal combustion, biomass burning + lightning, mobile sources, and microbial processes in F3 and F4 were $35.0 \pm 9.5 \%, 31.1 \pm 3.4 \%, 23.5 \pm 5.7 \%$, and $10.5 \pm 5.9 \%$ and $35.3 \pm 8.2 \%, 31.6 \pm 3.0 \%, 23.2 \pm 5.2 \%$, and $9.9 \pm 0.5 \%$, respectively. The source contributions to F3 and F4 showed no significant differences $(p>0.05)$, which may be due to their homology with B3, as reflected in their similar proportions (30\% in $\mathrm{B} 3$ and $31 \%$ in $\mathrm{F} 3$ and F4 combined). In addition, the correlation between source contributions in the weighted integration of F3 and F4 and those in B3 was close to 1.0 (SI Figure S11), indicating that such contributions could also represent the characteristics of local terrestrial sources in Karachi.

The contributions of coal combustion in B2 and B1 were $31.1 \pm 6.4 \%$ and $28.9 \pm 5.2 \%$, respectively. These contributions were reduced compared with F3 and F4; however, they were still close to $30 \%$. A similar situation occurred with the biomass burning + lightning source, which can be explained by the effects of secondary terrestrial emissions from the near-land sea area or local terrestrial sources when the sea breeze blows. A comparison between B2 and $\mathrm{B} 1$ revealed that the contribution of coal combustion in B1 was lower and originated from a more distant sea area. 
Correspondingly, mobile sources and microbial processes were more significant in B1 $(27.5 \pm 3.4 \%$ and $14.5 \pm 4.6 \%)$ compared with B2 $(25.9 \pm 4.1 \%$ and $12.8 \pm 5.4 \%)(p<0.01)$. Overall, the similar contributions of OL and LO trajectories suggest that most of the $\mathrm{NO}_{x}$ observed in the OL trajectory came from secondary terrestrial source contributions, and the decrease in the relative contributions from some sources was due to the addition of oceanic source contributions.

On the basis of the modeling method, the oceanic concentration of $\mathrm{NO}_{3}{ }^{-}$was estimated as $0.8 \mu \mathrm{g} \mathrm{m}{ }^{-3}$, contributing $16.8 \%$ to $\mathrm{NO}_{x}$ in the OL trajectory. This confirms the above-mentioned characteristics of the absolute contribution of terrestrial sources to $\mathrm{NO}_{x}$ in the OL trajectory. For the oceanic contribution, biomass burning + lightning, mobile sources, and microbial processes were $3.4 \%, 7.8 \%$, and $5.6 \%$, respectively. Excluding terrestrial sources (e.g., biomass burning and vehicle exhaust), the calculated $3.4 \%$ for biomass burning + lightning mostly came from lightning, and the $7.8 \%$ for mobile sources was due to shipping emissions, whereas the $5.6 \%$ portion for microbial processes was likely due to marine sediment and estuaries where the denitrification of microorganisms is vigorous. A previous study estimated that $11.3 \%$ of $\mathrm{NO}_{3}{ }^{-}$in 2013 came from ships, particularly in the Bohai and East China seas, which is higher than that calculated for Karachi in the AS region. ${ }^{75}$ These findings are consistent with the volume of ship activity in these areas (SI Figure S12). Looking at the ocean source as a whole, lightning, shipping emissions, and microbial process sources accounted for $20.3 \%$, $46.3 \%$, and $33.4 \%$, respectively, reflecting the high contribution of shipping emissions to the marine native $\mathrm{NO}_{x}$ in the AS region. Of course, it is conceivable that ships in East Asia, Europe, and North America, where ship activity is more frequent, contribute more to oceanic $\mathrm{NO}_{x}$; thus, shipping emissions should be integrated into area air management plans to reduce pollution levels. ${ }^{76}$

In summary, this study assessed the oceanic contributions to $\mathrm{NO}_{x}$ emissions using nitrogen isotope analysis. This novel evaluation method is expected to have a broad application range. It is undeniable that the apportionment results may have a certain uncertainty due to the lack of source values (e.g., the absence of shipping $\delta^{15} \mathrm{~N}-\mathrm{NO}_{x}$ ), but it is important to emphasize the dominant role of ship emissions in oceanic source contributions to the air pollution of surrounding areas.

\section{ASSOCIATED CONTENT}

\section{(s) Supporting Information}

The Supporting Information is available free of charge at https://pubs.acs.org/doi/10.1021/acs.est.0c00490.

Additional materials as noted in the text (PDF)

\section{AUTHOR INFORMATION}

\section{Corresponding Authors}

Chongguo Tian - CAS Key Laboratory of Coastal Environmental Processes and Ecological Remediation, Yantai Institute of Coastal Zone Research (YIC), Chinese Academy of Sciences (CAS), Yantai, Shandong 264003, P. R. China; Center for Ocean Mega-Science, Chinese Academy of Sciences, Qingdao

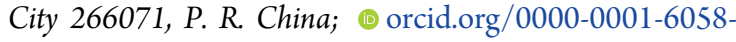
9353; Email: cgtian@yic.ac.cn

Jun Li - State Key Laboratory of Organic Geochemistry and Guangdong Key Laboratory of Environmental Protection and Resources Utilization, Guangzhou Institute of Geochemistry,
Chinese Academy of Sciences, Guangzhou 510640, China; ○ orcid.org/0000-0002-3637-1642; Email: junli@gig.ac.cn

\section{Authors}

Zheng Zong - CAS Key Laboratory of Coastal Environmental Processes and Ecological Remediation, Yantai Institute of Coastal Zone Research (YIC), Chinese Academy of Sciences (CAS), Yantai, Shandong 264003, P. R. China; Center for Ocean Mega-Science, Chinese Academy of Sciences, Qingdao City 266071, P. R. China

Jabir Hussain Syed - Department of Meteorology, COMSATS University Islamabad (CUI), Islamabad 45550, Pakistan; (1) orcid.org/0000-0003-0942-8495

Wei Zhang - School of Environmental and Material Engineering, Yantai University, Yantai, Shandong 264005, P. R. China

Yunting Fang - CAS Key Laboratory of Forest Ecology and Management, Institute of Applied Ecology, Chinese Academy of Sciences, Shenyang, Liaoning 110164, P. R. China; (1) orcid.org/0000-0001-7531-546X

Yifan Jiang - Department of Civil and Environmental Engineering, National University of Singapore, 117575 Singapore, Singapore

Jawad Nasir - Earth Sciences Directorate, Pakistan Space and Upper Atmosphere Research Commission (SUPARCO), Karachi 75270, Pakistan

Muhammad Mansha - Earth Sciences Directorate, Pakistan Space and Upper Atmosphere Research Commission (SUPARCO), Karachi 75270, Pakistan

Syed Hussain Haider Rizvi - Earth Sciences Directorate, Pakistan Space and Upper Atmosphere Research Commission (SUPARCO), Karachi 75270, Pakistan

Muhammad Shafiq - Earth Sciences Directorate, Pakistan Space and Upper Atmosphere Research Commission (SUPARCO), Karachi 75270, Pakistan; ㅇoㄷ․org/00000002-2570-1722

Suhaib Bin Farhan - Earth Sciences Directorate, Pakistan Space and Upper Atmosphere Research Commission (SUPARCO), Karachi 75270, Pakistan

Gan Zhang - State Key Laboratory of Organic Geochemistry and Guangdong Key Laboratory of Environmental Protection and Resources Utilization, Guangzhou Institute of Geochemistry, Chinese Academy of Sciences, Guangzhou 510640, China; (1) orcid.org/0000-0002-9010-8140

Complete contact information is available at: https://pubs.acs.org/10.1021/acs.est.0c00490

\section{Notes}

The authors declare no competing financial interest.

\section{ACKNOWLEDGMENTS}

This research was financially supported by the Natural Scientific Foundation of China (NSFC; Grants 41977190 and 41907198), the NSFC-Shandong Joint Fund (U1906215), Guangdong Foundation for Program of Science and Technology Research (Grant 2017B030314057), and the International Partnership Program of Chinese Academy of Sciences (Grant No. 132744KYSB20170002). The authors gratefully acknowledge the National Oceanic and Atmospheric Administration's Air Resources Laboratory for providing the HYSPLIT transport model. 


\section{REFERENCES}

(1) Galloway, J. N.; Dentener, F. J.; Capone, D. G.; Boyer, E. W.; Howarth, R. W.; Seitzinger, S. P.; Asner, G. P.; Cleveland, C. C.; Green, P. A.; Holland, E. A.; Karl, D. M.; Michaels, A. F.; Porter, J. H.; Townsend, A. R.; Vorosmarty, C. J. Nitrogen cycles: past, present, and future. Biogeochemistry 2004, 70 (2), 153-226.

(2) Cheng, Y.; Zheng, G.; Wei, C.; Mu, Q.; Zheng, B.; Wang, Z.; Gao, M.; Zhang, Q.; He, K.; Carmichael, G.; Poschl, U.; Su, H. Reactive nitrogen chemistry in aerosol water as a source of sulfate during haze events in China. Sci. Adv. 2016, 2 (12), No. e1601530.

(3) Fang, Y. T.; Koba, K.; Wang, X. M.; Wen, D. Z.; Li, J.; Takebayashi, Y.; Liu, X. Y.; Yoh, M. Anthropogenic imprints on nitrogen and oxygen isotopic composition of precipitation nitrate in a nitrogen-polluted city in southern China. Atmos. Chem. Phys. 2011, 11 (3), 1313-1325.

(4) Wang, G.; Zhang, R.; Gomez, M. E.; Yang, L.; Zamora, M. L.; Hu, M.; Lin, Y.; Peng, J.; Guo, S.; Meng, J.; Li, J.; Cheng, C.; Hu, T.; Ren, Y.; Wang, Y.; Gao, J.; Cao, J.; An, Z.; Zhou, W.; Li, G.; Wang, J.; Tian, P.; Marrero-Ortiz, W.; Secrest, J.; Du, Z.; Zheng, J.; Shang, D.; Zeng, L.; Shao, M.; Wang, W.; Huang, Y.; Wang, Y.; Zhu, Y.; Li, Y.; Hu, J.; Pan, B.; Cai, L.; Cheng, Y.; Ji, Y.; Zhang, F.; Rosenfeld, D.; Liss, P. S.; Duce, R. A.; Kolb, C. E.; Molina, M. J. Persistent sulfate formation from London Fog to Chinese haze. Proc. Natl. Acad. Sci. U. S. A. 2016, 113 (48), 13630-13635.

(5) Martin, R. V.; Jacob, D. J.; Chance, K.; Kurosu, T. P.; Palmer, P. I.; Evans, M. J. Global inventory of nitrogen oxide emissions constrained by space-based observations of $\mathrm{NO}_{2}$ columns. J. Geophys. Res. 2003, 108 (D17), 4537-4548.

(6) Fowler, D.; Coyle, M.; Skiba, U.; Sutton, M. A.; Cape, J. N.; Reis, S.; Sheppard, L. J.; Jenkins, A.; Grizzetti, B.; Galloway, J. N.; Vitousek, P.; Leach, A.; Bouwman, A. F.; Butterbach-Bahl, K.; Dentener, F.; Stevenson, D.; Amann, M.; Voss, M. The global nitrogen cycle in the twenty-first century. Philos. Trans. R. Soc., B 2013, 368 (1621), No. na.

(7) Zhang, F.; Chen, Y.; Chen, Q.; Feng, Y.; Shang, Y.; Yang, X.; Gao, H.; Tian, C.; Li, J.; Zhang, G.; Matthias, V.; Xie, Z. Real-World Emission Factors of Gaseous and Particulate Pollutants from Marine Fishing Boats and Their Total Emissions in China. Environ. Sci. Technol. 2018, 52 (8), 4910-4919.

(8) Corbett, J. J.; Fischbeck, P. S.; Pandis, S. N. Global nitrogen and sulfur inventories for oceangoing ships. J. Geophys. Res.-Atmos. 1999, 104 (D3), 3457-3470.

(9) Ding, J.; van der A, R. J.; Mijling, B.; Jalkanen, J.-P.; Johansson, L.; Levelt, P. F. Maritime $\mathrm{NO}_{\mathrm{x}}$ Emissions Over Chinese Seas Derived From Satellite Observations. Geophys. Res. Lett. 2018, 45 (4), 20312037.

(10) Shimadera, H.; Kojima, T.; Kondo, A.; Inoue, Y. Performance comparison of CMAQ and CAMx for one-year $\mathrm{PM}_{2.5}$ simulation in Japan. Int. J. Environ. Pollut. 2015, 57 (3-4), 146-161.

(11) Hastings, M. G.; Steig, E. J.; Sigman, D. M. Seasonal variations in $\mathrm{N}$ and $\mathrm{O}$ isotopes of nitrate in snow at Summit, Greenland: Implications for the study of nitrate in snow and ice cores. J. Geophys. Res. 2004, 109, D20306.

(12) Liu, X. Y.; Koba, K.; Koyama, L. A.; Hobbie, S. E.; Weiss, M. S.; Inagaki, Y.; Shaver, G. R.; Giblin, A. E.; Hobara, S.; Nadelhoffer, K. J.; Sommerkorn, M.; Rastetter, E. B.; Kling, G. W.; Laundre, J. A.; Yano, Y.; Makabe, A.; Yano, M.; Liu, C.-Q. Nitrate is an important nitrogen source for Arctic tundra plants. Proc. Natl. Acad. Sci. U. S. A. 2018, 115 (13), 3398-3403.

(13) Nilsson, L.; Widerlund, A. Tracing nitrogen cycling in mining waters using stable nitrogen isotope analysis. Appl. Geochem. 2017, 84, $41-51$.

(14) Xiao, H. W.; Xie, L. H.; Long, A. M.; Ye, F.; Pan, Y. P.; Li, D. N.; Long, Z. H.; Chen, L.; Xiao, H. Y.; Liu, C. Q. Use of isotopic compositions of nitrate in TSP to identify sources and chemistry in South China Sea. Atmos. Environ. 2015, 109, 70-78.

(15) Eriksson, E. on the Isotopic Composition of the Ammonia and the Nitrate Ion in RaiN. Geochim. Cosmochim. Acta 1958, 15 (1-2), 153-153.
(16) Freyer, H. D. Seasonal Trends of $\mathrm{NH}_{4}{ }^{+}$and $\mathrm{NO}_{3}{ }^{-}$Nitrogen Isotope Composition in Rain Collected at Julich, GermanY. Tellus 1978, 30 (1), 83-92.

(17) Freyer, H. D. Seasonal-Variation of N-15-N-14 Ratios in Atmospheric Nitrate Species. Tellus, Ser. B 1991, 43 (1), 30-44.

(18) Hoering, T. The Isotopic Composition of the Ammonia and the Nitrate Ion in Rain. Geochim. Cosmochim. Acta 1957, 12 (1-2), 97-102.

(19) Kamezaki, K.; Hattori, S.; Iwamoto, Y.; Ishino, S.; Furutani, H.; Miki, Y.; Uematsu, M.; Miura, K.; Yoshida, N. Tracing the sources and formation pathways of atmospheric particulate nitrate over the Pacific Ocean using stable isotopes. Atmos. Environ. 2019, 209, 152166.

(20) Kawashima, H.; Kurahashi, T. Inorganic ion and nitrogen isotopic compositions of atmospheric aerosols at Yurihonjo, Japan: Implications for nitrogen sources. Atmos. Environ. 2011, 45 (35), 6309-6316.

(21) Luo, L.; Wu, Y.; Xiao, H.; Zhang, R.; Lin, H.; Zhang, X.; Kao, S. $\mathrm{J}$. Origins of aerosol nitrate in Beijing during late winter through spring. Sci. Total Environ. 2019, 653, 776-782.

(22) Song, W.; Wang, Y. L.; Yang, W.; Sun, X. C.; Tong, Y. D.; Wang, X. M.; Liu, C. Q.; Bai, Z. P.; Liu, X. Y. Isotopic evaluation on relative contributions of major $\mathrm{NO}_{\mathrm{x}}$ sources to nitrate of $\mathrm{PM}_{2.5}$ in Beijing. Environ. Pollut. 2019, 248, 183-190.

(23) Widory, D. Nitrogen isotopes: Tracers of origin and processes affecting $\mathrm{PM}_{10}$ in the atmosphere of Paris. Atmos. Environ. 2007, 41 (11), 2382-2390.

(24) Elliott, E. M.; Yu, Z.; Cole, A. S.; Coughlin, J. G. Isotopic advances in understanding reactive nitrogen deposition and atmospheric processing. Sci. Total Environ. 2019, 662, 393-403.

(25) Felix, J. D.; Elliott, E. M.; Shaw, S. L. Nitrogen isotopic composition of coal-fired power plant $\mathrm{NO}_{\mathrm{x}}$ : influence of emission controls and implications for global emission inventories. Environ. Sci. Technol. 2012, 46 (6), 3528-35.

(26) Fibiger, D. L.; Hastings, M. G. First Measurements of the Nitrogen Isotopic Composition of $\mathrm{NO}_{\mathrm{x}}$ from Biomass Burning. Environ. Sci. Technol. 2016, 50 (21), 11569-11574.

(27) Miller, D. J.; Chai, J.; Guo, F.; Dell, C. J.; Karsten, H.; Hastings, M. G. Isotopic Composition of In Situ Soil $\mathrm{NO}_{\mathrm{x}}$ Emissions in Manure-Fertilizes Cropland. Geophys. Res. Lett. 2018, 45 (21), 12058-12066.

(28) Miller, D. J.; Wojtal, P. K.; Clark, S. C.; Hastings, M. G. Vehicle $\mathrm{NO}_{\mathrm{x}}$ emission plume isotopic signatures: Spatial variability across the eastern United States. J. Geophys. Res.-Atmos. 2017, 122 (8), 46984717.

(29) Walters, W. W.; Tharp, B. D.; Fang, H.; Kozak, B. J.; Michalski, G. Nitrogen Isotope Composition of Thermally Produced $\mathrm{NO}_{\mathrm{x}}$ from Various Fossil-Fuel Combustion Sources. Environ. Sci. Technol. 2015, 49 (19), 11363-71.

(30) Yu, Z.; Elliott, E. M. Novel Method for Nitrogen Isotopic Analysis of Soil-Emitted Nitric Oxide. Environ. Sci. Technol. 2017, 51 (11), 6268-6278.

(31) Walters, W. W.; Michalski, G. Theoretical calculation of nitrogen isotope equilibrium exchange fractionation factors for various $\mathrm{NO}_{\mathrm{y}}$ molecules. Geochim. Cosmochim. Acta 2015, 164, 284-297.

(32) Walters, W. W.; Michalski, G. Theoretical calculation of oxygen equilibrium isotope fractionation factors involving various $\mathrm{NO}_{\mathrm{y}}$ molecules, $\mathrm{OH}$, and $\mathrm{H}_{2} \mathrm{O}$ and its implications for isotope variations in atmospheric nitrate. Geochim. Cosmochim. Acta 2016, 191, 89-101.

(33) Parnell, A. C.; Phillips, D. L.; Bearhop, S.; Semmens, B. X.; Ward, E. J.; Moore, J. W.; Jackson, A. L.; Grey, J.; Kelly, D. J.; Inger, R. Bayesian stable isotope mixing models. Environmetrics 2013, 24 (6), 387-399.

(34) Lu, Y.; Lin, S.; Fatmi, Z.; Malashock, D.; Hussain, M. M.; Siddique, A.; Carpenter, D. O.; Lin, Z.; Khwaja, H. A. Assessing the association between fine particulate matter $\left(\mathrm{PM}_{2.5}\right)$ constituents and cardiovascular diseases in a mega-city of Pakistan. Environ. Pollut. 2019, 252, 1412-1422. 
(35) Khan, Z. Y.; Kettler, J.; Khwaja, H. A.; Naqvi, I. I.; Malik, A.; Stone, E. A. Organic Aerosol Characterization and Source Identification in Karachi, Pakistan. Aerosol Air Qual. Res. 2018, 18 (10), 2550-2564.

(36) Khwaja, H. A.; Fatmi, Z.; Malashock, D.; Aminov, Z.; Kazi, A.; Siddique, A.; Qureshi, J.; Carpenter, D. O. Effect of air pollution on daily morbidity in Karachi, Pakistan. J. Local Glob. Health Sci. 2012, $217,1-13$.

(37) Liao, X.; Zhan, H.; Du, Y. Potential new production in two upwelling regions of the western Arabian Sea: Estimation and comparison. J. Geophys. Res.: Oceans 2016, 121 (7), 4487-4502.

(38) Zong, Z.; Tan, Y.; Wang, X.; Tian, C.; Fang, Y.; Chen, Y.; Fang, Y.; Han, G.; Li, J.; Zhang, G. Assessment and quantification of $\mathrm{NO}_{\mathrm{x}}$ sources at a regional background site in North China: Comparative results from a Bayesian isotopic mixing model and a positive matrix factorization model. Environ. Pollut. 2018, 242, 1379-1386.

(39) McIlvin, M. R.; Altabet, M. A. Chemical conversion of nitrate and nitrite to nitrous oxide for nitrogen and oxygen isotopic analysis in freshwater and seawater. Anal. Chem. 2005, 77 (17), 5589-5595.

(40) Harrison, R. L. Introduction To Monte Carlo Simulation. AIP Conf. Proc. 2010, 1204, 17-21.

(41) Moore, J. W.; Semmens, B. X. Incorporating uncertainty and prior information into stable isotope mixing models. Ecol. Lett. 2008, 11 (5), 470-480.

(42) Walters, W. W.; Simonini, D. S.; Michalski, G. Nitrogen isotope exchange between $\mathrm{NO}$ and $\mathrm{NO}_{2}$ and its implications for $\delta^{15} \mathrm{~N}$ variations in tropospheric $\mathrm{NO}_{\mathrm{x}}$ and atmospheric nitrate. Geophys. Res. Lett. 2016, 43 (1), 440-448.

(43) Zong, Z.; Wang, X.; Tian, C.; Chen, Y.; Fang, Y.; Zhang, F.; Li, C.; Sun, J.; Li, J.; Zhang, G. First Assessment of $\mathrm{NO}_{\mathrm{x}}$ Sources at a Regional Background Site in North China Using Isotopic Analysis Linked with Modeling. Environ. Sci. Technol. 2017, 51 (11), 59235931.

(44) Heaton, E. T. H. ${ }^{15} \mathrm{~N} /{ }^{14} \mathrm{~N}$ rations of $\mathrm{NO}_{\mathrm{x}}$ from vehicle engines and coal-fired power stations. Tellus, Ser. B 1990, 42, 304-307.

(45) Walters, W. W.; Goodwin, S. R.; Michalski, G. Nitrogen stable isotope composition $\delta^{15} \mathrm{~N}$ of vehicle-emitted $\mathrm{NO}_{\mathrm{x}}$. Environ. Sci. Technol. 2015, 49 (4), 2278-85.

(46) Li, D.; Wang, X. Nitrogen isotopic signature of soil-released nitric oxide (NO) after fertilizer application. Atmos. Environ. 2008, 42 (19), 4747-4754.

(47) Felix, J. D.; Elliott, E. M. Isotopic composition of passively collected nitrogen dioxide emissions: Vehicle, soil and livestock source signatures. Atmos. Environ. 2014, 92, 359-366.

(48) Bressi, M.; Sciare, J.; Ghersi, V.; Mihalopoulos, N.; Petit, J. E.; Nicolas, J. B.; Moukhtar, S.; Rosso, A.; Féron, A.; Bonnaire, N.; Poulakis, E.; Theodosi, C. Sources and geographical origins of fine aerosols in Paris (France). Atmos. Chem. Phys. 2014, 14 (16), 88138839.

(49) Earl, D. J.; Deem, M. W. Monte Carlo simulations. Methods Mol. Biol. (N. Y., NY, U. S.) 2008, 443, 25-36.

(50) Mansha, M.; Ghauri, B.; Rahman, S.; Amman, A. Characterization and source apportionment of ambient air particulate matter $\left(\mathrm{PM}_{2.5}\right)$ in Karachi. Sci. Total Environ. 2012, 425, 176-83.

(51) Shahid, I.; Kistler, M.; Mukhtar, A.; Ghauri, B. M.; RamirezSanta Cruz, C.; Bauer, H.; Puxbaum, H. Chemical characterization and mass closure of $\mathrm{PM}_{10}$ and $\mathrm{PM}_{2.5}$ at an urban site in Karachi Pakistan. Atmos. Environ. 2016, 128, 114-123.

(52) Shahid, I.; Alvi, M. U.; Shahid, M. Z.; Alam, K.; Chishtie, F. Source Apportionment of $\mathrm{PM}_{10}$ at an Urban Site of a South Asian Mega City. Aerosol Air Qual. Res. 2018, 18 (9), 2498-2509.

(53) An, Z.; Huang, R.-J.; Zhang, R.; Tie, X.; Li, G.; Cao, J.; Zhou, W.; Shi, Z.; Han, Y.; Gu, Z.; Ji, Y. Severe haze in northern China: A synergy of anthropogenic emissions and atmospheric processes. Proc. Natl. Acad. Sci. U. S. A. 2019, 116 (18), 8657-8666.

(54) Hastings, M. G.; Jarvis, J. C.; Steig, E. J. Anthropogenic impacts on nitrogen isotopes of ice-core nitrate. Science 2009, 324 (5932), 1288 .
(55) Song, W.; Liu, X.-Y.; Wang, Y.-L.; Tong, Y.-D.; Bai, Z.-P.; Liu, C.-Q. Nitrogen isotope differences between atmospheric nitrate and corresponding nitrogen oxides: A new constraint using oxygen isotopes. Sci. Total Environ. 2020, 701, 134515.

(56) Alexander, B.; Hastings, M. G.; Allman, D. J.; Dachs, J.; Thornton, J. A.; Kunasek, S. A. Quantifying atmospheric nitrate formation pathways based on a global model of the oxygen isotopic composition $\left(\Delta \mathrm{O}^{17}\right)$ of atmospheric nitrate. Atmos. Chem. Phys. 2009, 9 (14), 5043-5056.

(57) Elliott, E. M.; Kendall, C.; Boyer, E. W.; Burns, D. A.; Lear, G. G.; Golden, H. E.; Harlin, K.; Bytnerowicz, A.; Butler, T. J.; Glatz, R. Dual nitrate isotopes in dry deposition: Utility for partitioning $\mathrm{NO}_{\mathrm{x}}$ source contributions to landscape nitrogen deposition. J. Geophys. Res. 2009, 114, G04020.

(58) Ahern, A. T.; Goldberger, L.; Jahl, L.; Thornton, J.; Sullivan, R. C. Production of $\mathrm{N}_{2} \mathrm{O}_{5}$ and $\mathrm{ClNO}_{2}$ through Nocturnal Processing of Biomass-Burning Aerosol. Environ. Sci. Technol. 2018, 52 (2), 550559.

(59) Lu, K.; Fuchs, H.; Hofzumahaus, A.; Tan, Z.; Wang, H.; Zhang, L.; Schmitt, S. H.; Rohrer, F.; Bohn, B.; Broch, S.; Dong, H.; Gkatzelis, G. I.; Hohaus, T.; Holland, F.; Li, X.; Liu, Y.; Liu, Y.; Ma, X.; Novelli, A.; Schlag, P.; Shao, M.; Wu, Y.; Wu, Z.; Zeng, L.; Hu, M.; Kiendler-Scharr, A.; Wahner, A.; Zhang, Y. Fast Photochemistry in Wintertime Haze: Consequences for Pollution Mitigation Strategies. Environ. Sci. Technol. 2019, 53 (18), 10676-10684.

(60) Xue, L.; Wang, T.; Louie, P. K. K.; Luk, C. W. Y.; Blake, D. R.; $\mathrm{Xu}, \mathrm{Z}$. Increasing External Effects Negate Local Efforts to Control Ozone Air Pollution: A Case Study of Hong Kong and Implications for Other Chinese Cities. Environ. Sci. Technol. 2014, 48 (18), 10769-10775.

(61) Iqbal, M.; Syed, J. H.; Breivik, K.; Chaudhry, M. J. I.; Li, J.; Zhang, G.; Malik, R. N. E-Waste Driven Pollution in Pakistan: The First Evidence of Environmental and Human Exposure to Flame Retardants (FRs) in Karachi City. Environ. Sci. Technol. 2017, 51 (23), 13895-13905.

(62) Alam, K.; Rahman, N.; Khan, H. U.; Haq, B. S.; Rahman, S. Particulate Matter and Its Source Apportionment in Peshawar, Northern Pakistan. Aerosol Air Qual. Res. 2015, 15 (2), 634-647.

(63) Alam, K.; Trautmann, T.; Blaschke, T.; Majid, H. Aerosol optical and radiative properties during summer and winter seasons over Lahore and Karachi. Atmos. Environ. 2013, 74, 412-412.

(64) Lodhi, A.; Ghauri, B.; Khan, M. R.; Rahman, S.; Shafique, S. Particulate Matter $\left(\mathrm{PM}_{2.5}\right)$ Concentration and Source Apportionment in Lahore. J. Braz. Chem. Soc. 2009, 20 (10), 1811-1820.

(65) Chen, F.; Lao, Q.; Jia, G.; Chen, C.; Zhu, Q.; Zhou, X. Seasonal variations of nitrate dual isotopes in wet deposition in a tropical city in China. Atmos. Environ. 2019, 196, 1-9.

(66) China Statistical Yearbook, Part XVI: Transport, Post, And Telecommunication Services; China Statistics Press: Beijing, China, 2017.

(67) Ramacher, M. O. P.; Karl, M.; Bieser, J.; Jalkanen, J.-P.; Johansson, L. Urban population exposure to $\mathrm{NO}_{\mathrm{x}}$ emissions from local shipping in three Baltic Sea harbour cities - a generic approach. Atmos. Chem. Phys. 2019, 19 (14), 9153-9179.

(68) Rehman, S. A. U.; Cai, Y.; Mirjat, N. H.; Das Walasai, G.; Shah, I. A.; Ali, S. The Future of Sustainable Energy Production in Pakistan: A System Dynamics-Based Approach for Estimating Hubbert Peaks. Energies 2017, 10, 1858.

(69) China Statistical Yearbook, Part IX: Energy; China Statistics Press: Beijing, China, 2017.

(70) Liu, F.; Beirle, S.; Zhang, Q.; van der A, R. J.; Zheng, B.; Tong, D.; He, $\mathrm{K} . \mathrm{NO}_{\mathrm{x}}$ emission trends over Chinese cities estimated from OMI observations during 2005 to 2015. Atmos. Chem. Phys. 2017, 17 (15), 9261-9275.

(71) Zong, Z.; Tan, Y.; Wang, X.; Tian, C.; Li, J.; Fang, Y.; Chen, Y.; Cui, S.; Zhang, G. Dual-modelling-based source apportionment of $\mathrm{NO}_{\mathrm{x}}$ in five Chinese megacities: Providing the isotopic footprint from 2013 to 2014. Environ. Int. 2020, 137, 105592-105592. 
(72) Ning, J.; Liu, J.; Kuang, W.; Xu, X.; Zhang, S.; Yan, C.; Li, R.; Wu, S.; Hu, Y.; Du, G.; Chi, W.; Pan, T.; Ning, J. Spatiotemporal patterns and characteristics of land-use change in China during 20102015. J. Geogr. Sci. 2018, 28 (5), 547-562.

(73) Colbeck, I.; Nasir, Z. A.; Ali, Z. The state of ambient air quality in Pakistan-a review. Environ. Sci. Pollut. Res. 2010, 17 (1), 49-63.

(74) Zhang, X.; Zhang, Y.; Liu, Y.; Zhao, J.; Zhou, Y.; Wang, X.; Yang, X.; Zou, Z.; Zhang, C.; Fu, Q.; Xu, J.; Gao, W.; Li, N.; Chen, J. Changes in the $\mathrm{SO}_{2}$ Level and $\mathrm{PM}_{2.5}$ Components in Shanghai Driven by Implementing the Ship Emission Control Policy. Environ. Sci. Technol. 2019, 53 (19), 11580-11587.

(75) Zhang, F.; Chen, Y.; Tian, C.; Lou, D.; Li, J.; Zhang, G.; Matthias, V. Emission factors for gaseous and particulate pollutants from offshore diesel engine vessels in China. Atmos. Chem. Phys. 2016, 16 (10), 6319-6334.

(76) Corbett, J. J.; Winebrake, J. J.; Green, E. H.; Kasibhatla, P.; Eyring, V.; Lauer, A. Mortality from ship emissions: A global assessment. Environ. Sci. Technol. 2007, 41 (24), 8512-8518. 